\title{
CAMBRIDGE
}

New Titles from Cambridge University Press

The Letters of Samuel Beckett Volume 2: 1941-1956

Samuel Beckett

Edited by George Craig,

Martha Dow Fehsenfeld,

Dan Gunn, and

Lois More Overbeck

The Letters of Samuel Beckett

\$50.00: Hb: 978-0-521-86794-8: $886 \mathrm{pp}$.

The Making of the West End Stage

Marriage, Management and the

Mapping of Gender in London,

1830-1870

Jacky Bratton

s99.00: $\mathrm{Hb}: 978-0-521-51901-4: 230 \mathrm{pp}$.

Twentieth-Century British Theatre Industry, Art and Empire

Claire Cochrane

\$99.00: Hb: 978-0-521-46488-8: $364 \mathrm{pp}$.

The African American

Theatrical Body

Reception, Performance, and the Stage

Soyica Diggs Colbert

599.00: Hb: 978-1-107-01438-1: 344 pp.

A History of Theatre in Spain

Edited by Maria M. Delgado and

David T. Gies

\$120.00: Hb: 978-0-521-11769-2: 450 pp.

Nabokov's Theatrical Imagination

Siggy Frank

\$90.00: Hb: 978-1-107-01545-6: 232 pp.

\section{Chinese Theatre}

$\mathrm{Jin} \mathrm{Fu}$

Introductions to Chinese Culture

S19.99: Pb: 978-0-521-18666-7: 153 pp.

David Mamet and American Macho

Arthur Holmberg

Cambridge Studies in

American Theatre and Drama

\$90.00: Hb: 978-0-521-62064-2: $336 \mathrm{pp}$.

Prices subject to change.
Sexual Politics in the Work of Tennessee Williams Desire Over Protest

Michael S. D. Hooper

\$99.00: Hb: 978-1-107-01536-4: $272 \mathrm{pp}$.

Performing Greek Comedy

Alan Hughes

\$99.00: Hb: 978-1-107-00930-1: 328 pp.

\section{Volume Set}

The Cambridge Edition of the Works of Ben Jonson

Ben Jonson.

Edited by David Bevington,

Martin Butler, and Ian Donaldson

\$990.00: $7 \mathrm{Hb}$ books: 978-0-521-78246-3:

$5,400 \mathrm{pp}$

Dion Boucicault

Irish Identity on Stage

Deirdre McFeely

s99.00: Hb: 978-1-107-00793-2: 340 pp.

\section{The Cambridge Introduction to}

Christopher Marlowe

Tom Rutter

Cambridge Introductions to Literature \$75.00: Hb: 978-0-521-19634-5: 166 pp. 519.99: Pb: 978-0-521-12430-0

Intimacy and Sexuality in the Age of Shakespeare James M. Bromley 595.00: Hb: 978-1-107-01518-0: 218 pp.

\section{Shakespeare Survey}

Volume 64: Shakespeare as Cultural Catalyst

Edited by Peter Holland

Shakespeare Survey

\$120.00: Hb: 978-1-107-01122-9: $472 \mathrm{pp}$.

Shakespeare,

Rhetoric and Cognition

Raphael Lyne

s90.00: $\mathrm{Hb}$ : 978-1-107-00747-5: 276 pp.
Shakespeare,

Time and the Victorians A Pictorial Exploration

Stuart Sillars

\$99.00: $\mathrm{Hb}: 978-0-521-50969-5: 384 \mathrm{pp}$.

Theatre and Testimony in Shakespeare's England A Culture of Mediation Holger Schott Syme s95.00: Hb: 978-1-107-01185-4: 298 pp.

Shakespeare in the Eighteenth Century Edited by Fiona Ritchie and Peter Sabor

599.00: Hb: 978-0.521-89860-7: $480 \mathrm{pp}$

Shakespeare in the Nineteenth Century

Edited by Gail Marshall \$99.00: $\mathrm{Hb}: 978-0-521-51824-6: 480 \mathrm{pp}$

\section{The Cambridge}

Shakespeare Guide

Emma Smith

\$75.00: Hb: 978-0-521-19523-2: 264 pp. S18.99: Pb: 978-0-521-14972-3

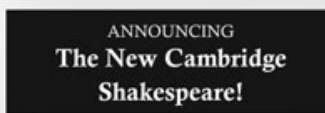

VISIT

www.cambridge.org/us to learn more!

Second Edition

The Two Gentlemen of Verona Edited by Kurt Schlueter \$85.00: Hb: 978-1-107-00489-4: 184 pp. \$16.99: Pb: 978-0-521-18169-3

The Two Noble Kinsmen Edited by Robert Kean Turner and Patricia Tatspaugh

585.00: Hb: 978-0.521-43270-2: 248 pp. S16.99: Pb: $978-0-521-68699-0$ 


\section{CAMBRIDGE JOURNALS}

AVene Quarterly University of London, UK Simon Trussler, Rose Bruford College, UK

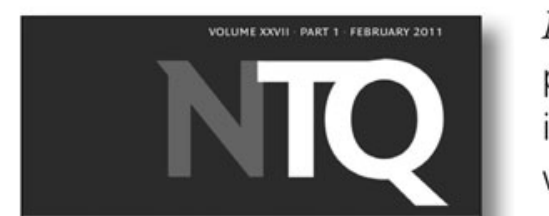

NEW THEATRE QUARTERLY 105

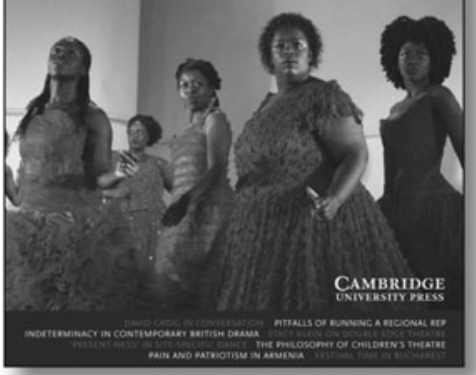

New Theatre Quarterly provides a vital international forum where theatrical scholarship and practice can meet and where prevailing dramatic assumptions can be subjected to vigorous critical questioning. It shows that theatre history has a contemporary relevance, that theatre studies need a methodology and that theatre criticism needs a language. The journal publishes news, analysis and debate within the field of theatre studies.

FREE email alerts. Keep up-to-date with new material. Sign up at: journals.cambridge.org/ntq-alerts

Recommend

New Theatre Quarterly directly from its homepage -

FRE online access for you when your library subscribes.

journals.cambridge.org/ntq 


\section{CAMBRIDGE}

\section{JDURNALS}

Published

for the

International

Federation for

Theatre Research

\section{Theatre}

Research

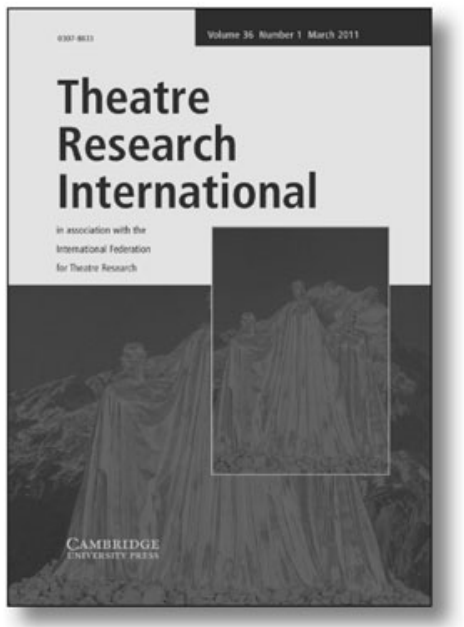

International

EDITORS:

ElaIne Aston, Lancaster University, UK Charlotte Canning, University of Texas at Austin, USA

Theatre Research International publishes articles on theatre practices in their social, cultural, and historical contexts, their relationship to other media of representation, and to other fields of inquiry. The journal seeks to reflect the evolving diversity of critical idioms prevalent in the scholarship of differing world contexts.

FREE email alerts.

Keep up-to-date with new material. Sign up at: journals.cambridge.org/tri-alerts

Recommend

Theatre Research International directly from its homepage FREE online access for you when your library subscribes.

journals.cambridge.org/tri UNIVERSITY PRESS 


\section{CAMBRIDGE JURNALS}

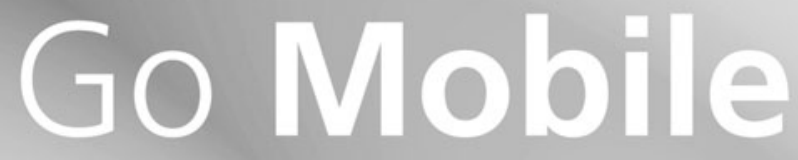

CJO Mobile $(\mathrm{CJOm})$ is a streamlined

Cambridge Journals Online (CJO)

for smartphones and other

small mobile devices

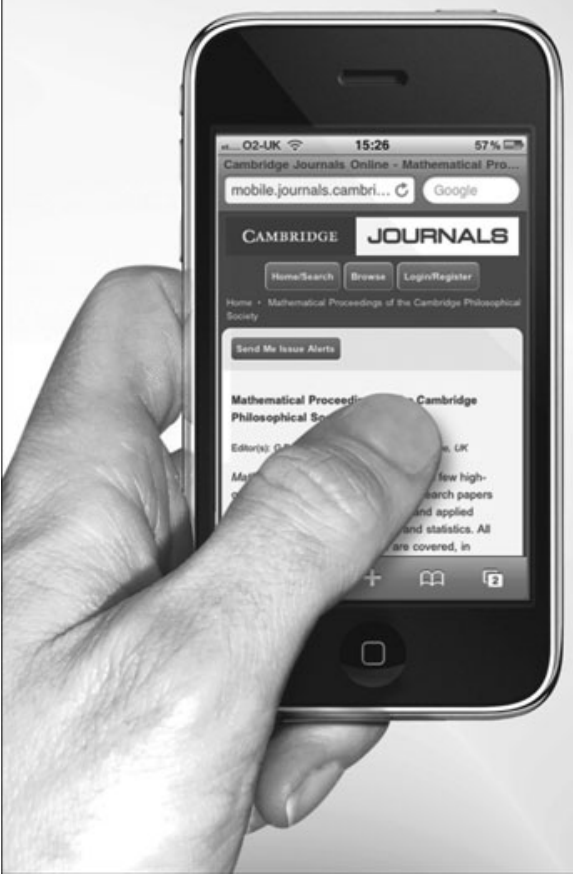

- Use CJOm to access all journal content including FirstView articles which are published online ahead of print

- Access quickly and easily thanks to simplified design and low resolution images

- Register for content alerts or save searches and articles they will be available on both CJO and CJOm

- Your device will be detected and automatically directed to CJOm via: journals.cambridge.org 


\title{
The American Society for Theatre Research
}

The American Society for Theatre Research (ASTR) is a U.S.-based professional organization that fosters scholarship on worldwide theatre and performance, both historical and contemporary. ASTR was founded in 1956 to encourage theatre scholarship in the United States and to provide a link to similar research-oriented organizations, such as the International Federation for Theatre Research/La Fédération Internationale pour la Recherche Théâtrale (IFTR/FIRT). ASTR was incorporated under the laws of the state of New Jersey as a nonprofit corporation in 1967, and is the only theatre organization in the United States formally affiliated with both the American Council of Learned Societies and with the IFTR/FIRT. The ASTR Annual Meeting occurs in the fall of each year.

Theatre Survey, the official journal of ASTR, is published biannually in April and September, and is one of the benefits of membership in the Society. ASTR annual dues for North Americans are $\$ 115.00$ for individual members, $\$ 40.00$ for retired members, $\$ 35.00$ for students. Foreign members pay an additional $\$ 7.50$ in each of the above categories. Inquiries about ASTR, including membership, should be directed to:

\author{
Nancy Erickson \\ NEricksn@aol.com
}

The American Society for Theatre Research

P.O. Box 1798

Boulder, CO 80306-1798

Telephone: (888) 530-1838

Fax: (303) 530-1839

http://www.astr.org/

\section{Officers And Executive Committee of ASTR}

\author{
Rhonda Blair (President, 2009-2012) \\ Stacy Wolf (Vice-President, 2009-2012) \\ Marla Carlson (Secretary, 2011-2014) \\ Cindy Brizzell-Bates (Treasurer, 2011-2014) \\ Executive Committee members \\ Susan Bennett (2009-2012) \\ Dorothy Chansky (2009-2012) \\ Gay Gibson Cima (2010-2013) \\ Soyica Colbert (2011-2014) \\ Laura Edmondson (2009-2012) \\ Elinor Fuchs (2010-2013) \\ Brian Herrera (2010-2013) \\ David Calder (Graduate Student Representative, 2011-2012) \\ Suk-Young Kim (2011-2014) \\ Heather Nathans (2010-2013) \\ Kirsten Pullen (2011-2014) \\ Mike Sell (2009-2012) \\ Leigh Woods (2011-2014)
}




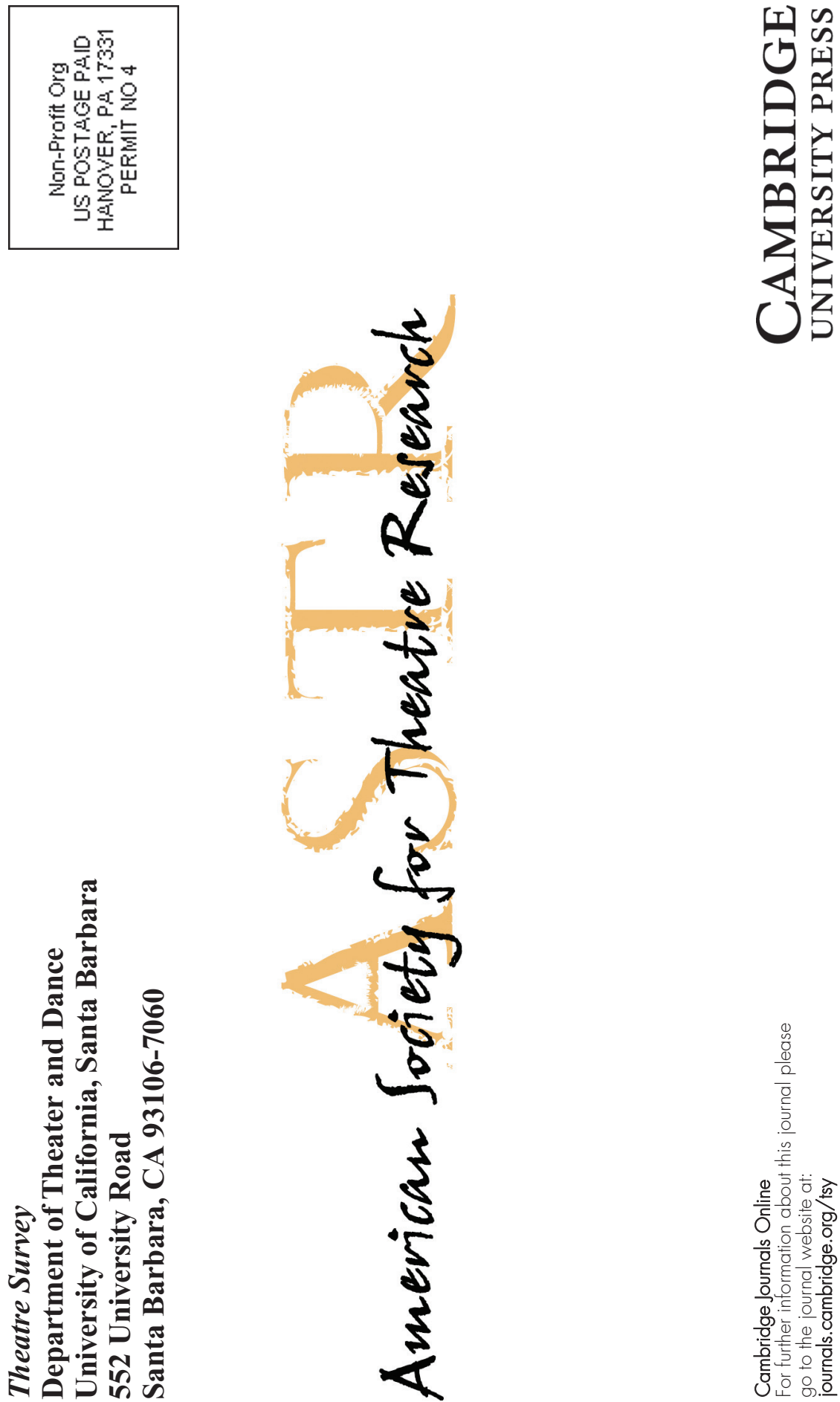

